\title{
The high density of plants increases the radiation use efficiency of photosynthetically active seedlings of Japanese grape (Hovenia dulcis)
}

\author{
Felipe Schwerz ${ }^{1}$, Braulio Otomar Caron ${ }^{1}$, Elvis Felipe Elli ${ }^{1}$, Elder Eloy ${ }^{2}$, Denise Schmidt ${ }^{1}$, John \\ Robert Stolzle $^{1}$, Sandro Luiz Petter Medeiros ${ }^{3}$, Jaqueline Sgarbossa ${ }^{1}$, Rômulo Trevisan ${ }^{2}$
}

${ }^{1}$ Department of Agronomic Sciences, Federal University of Santa Maria, Frederico Westphalen Campus, 98400 000, Frederico Westphalen, Rio Grande do Sul, Brazil ${ }^{2}$ Department of Forest Engineering, Federal University of Santa Maria, Frederico Westphalen Campus, 98400000, Frederico Westphalen, Rio Grande do Sul, Brazil

${ }^{3}$ Department of Plant Science, Federal University of Santa Maria, Santa Maria, Rio Grande do Sul, Brazil

*Corresponding author: felipe_schwerz@hotmail.com

\begin{abstract}
The objective of this study was to determine the use efficiency intercepted photosynthetically active solar radiation of Hovenia dulcis seedlings grown under different plant density treatments. The experiment was conducted in a greenhouse at the forestry nursery. A complete randomized block design was applied. The study was characterized by two plant densities; high $\left(494\right.$ plants $\left.\mathrm{m}^{-2}\right)$ and medium (247 plants $\mathrm{m}^{-2}$ ) densities of seedling in the trays, and fifteen evaluation periods that began after first emergence. Evaluations were carried out every 15 days, totaling 210 days, with six replications. The leaf area index, total dry biomass of seedlings, partitioning of dry biomass, interception of global radiation, accumulated intercepted photosynthetically active radiation, and use efficiency of radiation were evaluated. The high density treatments promoted greater use efficiency and accumulation of intercepted photosynthetically active radiation in dry biomass of Hovenia dulcis seedlings. In this work, a model is present for analyzing the growth and development of plants and their relation to both photosynthetic rate and radiation use efficiency.
\end{abstract}

Keywords: solar radiation; leaf area index; assimilated partition; plant growth; Japanese grape.

Abbreviations: DAE_days after emergence, ETA_explored tray area, GRI_global radiation interception, K_extinction coefficient, LA_leaf area, LAI_leaf area index, PAR_photosynthetically active radiation, RG_incident solar radiation in the exterior of the greenhouse, RGE_solar radiation in the interior of greenhouse, TDM_total dry matter, $\varepsilon b \_$radiation use efficiency.

\section{Introduction}

Hovenia dulcis Thunberg belongs to Rhamnaceae family, also known as "Japanese Grape", it is an exotic species that has many uses. The plant presents rapid growth, and has a potential for timber extraction (Schumacher et al., 2008). This species is adequate for use in agroforestry systems, commercial forestation, and environmental reforestation. The implementation of this species in different forest systems is often started with seedlings produced in greenhouses. Cultivation in greenhouses can cause changes in meteorological elements including solar radiation; in the interior of greenhouses, this element is one of the first to be modified (Caron et al., 2012).

The growth of plants is a function of the accumulated biomass through photosynthesis. The dependence of photosynthetic processes on the environment is of interest to professionals who work in the agricultural sciences, because the productivity of a plant, and its crop yield, is dependent upon its photosynthetic rates in an environment (Taiz and Zeiger, 2013). Biomass production in plants depends upon the quantity of absorbed photosynthetically active radiation (PARa) by leaves, and the efficiency by which the leaves can convert and assimilate the radiant through photosynthesis. Thus, the intercepted photosynthetically active radiation (PARi) that is converted into biomass, reveals the efficiency of the use of radiation $(\varepsilon b)$ by species (Monteith, 1977). In most cases, this process presents a linear function, as observed in the works developed by Stape et al. (2008); Campoe et al. (2013); Caron et al. (2014), among others. One of the factors that is known to influence the $\varepsilon b$ is the leaf area index (LAI), a characteristic that can be modified by the density of seedlings. Research into the spacing of plants should be conducted in order to shorten the production cycle for the culture and to maximize the interception of solar radiation per unit area and time. Those studies should be conducted by analyzing the photosynthetic efficiency is, which is a direct function of plant density, where LAI determines the $\varepsilon b$ according to Villa Nova et al. (2003).

It is important to study the efficiency of this species in order to identify the productive potential and the limiting factors to productivity. This is especially relevant, considering its importance as an alternative for forestry production, as well as that the conversion of the PAR to dry matter varies among species of economic interest. There is an absence of studies regarding the growth of seedlings; thus, the objective of this study was to determine the use efficiency of intercepted photosynthetically active solar radiation by analyzing the dry matter of seedlings Hovenia dulcis, planted in different densities. 


\section{Results and Discussion}

\section{Flux of global solar radiation}

The flux of global solar radiation was, on average 14.13 $\mathrm{MJ} . \mathrm{m}^{-2} \cdot \mathrm{dia}^{-1}$ with variation of 1.37 to $33.90 \mathrm{MJ} \cdot \mathrm{m}^{-2} \cdot \mathrm{dia}^{-1}$; in the greenhouse the average was $8.90 \mathrm{MJ} \cdot \mathrm{m}^{-2} \cdot \mathrm{dia}^{-1}$, with a variation of 0.86 to $21.36 \mathrm{MJ} \cdot \mathrm{m}^{-2} \cdot \mathrm{dia}^{-1}$. The availability of solar incident radiation in the greenhouse environment was lower due to plastic transmissivity; this reduction can however be offset by an increase of the fraction of diffuse radiation.

\section{Use efficiency of solar radiation is influenced by density of plants}

Growth of total dry matter (TDM) presented a positive linear relationship with PARia, with high correlation coefficients and a dependent response to seedling density. The same was observed with the LAI (Fig 1A and 1B).

Through the obtained angular coefficients, which expressing the value of $\varepsilon b$ by seedlings, it was observed that by increasing the density seedlings in the tray an increase occurred in LAI, and consequently resulted in a higher use efficiency of radiation. The efficiency of interception of photosynthetically active radiation is directly related to the LAI, being that this factor influences the amount, duration of leaf area, and production potential of dry matter (Mayers et al., 1991). The increase in LAI results in higher levels of intercepted solar radiation (Caron et al., 2014).

In the medium density treatment, the use efficiency of radiation in the TDM of seedlings was $2.16 \mathrm{~g} \mathrm{MJ}^{-1}$ and 2.40 $\mathrm{g} \mathrm{MJ}^{-1}$ for the high density treatment, ie, $10 \%$ higher (Figure 1A). The observed values for the high density of plants may be related to rapid occupation of leaf area in the space between the seedlings as evidenced by the higher LAI (Figure 1B). The increased LAI improved the percent of intercepted photosynthetically active radiation.

The rapid vegetative growth of the seedlings in the tray, resulted in the ability for plants to more efficiency absorb multidirectional diffuse radiation (Buriol et al., 1995). Diffuse radiation promotes greater radial uniformity of the plants, and improves overall efficiency because lower leaves are able to absorb radiation.

These results are in accordance with those obtained by Sanquetta et al. (2014), working with seedlings of Eucalyptus dunni, whom found higher use efficiency of radiation in the high density of plants per tray. Caron et al. (2012) observed that increasing the density of Eucalyptus grandis seedlings increased the use efficiency of radiation by $44 \%$.

The values for use efficiency of radiation in seedlings Hovenia dulcis, obtained in this study, was lower than what has been observed in crops grown within greenhouses; for example, Eucalyptus dunnii grown by Sanquetta et al. (2014) presented $7.75 \mathrm{~g} \mathrm{MJ}^{-1}$, in those submitted to high density, and $5.57 \mathrm{~g} \mathrm{MJ}^{-1}$ to the medium density. In the literature, a minimal amount of relevant research exists regarding this species. The use efficiency of solar radiation directly relates to the growth and development of plants, and consequently rate of growth, and overall plant yields.

\section{The interception of solar radiation is increased with the increment of LAI}

Based on the analysis of variance, significant differences for all analyzed variables were observed. The regression equations presented high correlation coefficients for the
TDM, LAI, PARia, and global radiation interception (GRI) when related to days after emergence (Fig 2A, 2B, 2C and 2D).

With the higher seedling density in the trays, the accumulated TDM presented an increase in values, according to Ataíde et al. (2010) and Caron et al. (2014). The major accumulation of dry matter, obtained as a function of days after emergence in the treatment of high density, is associated to LAI. A high LAI is associated with high PARi, and consequently, greater TDM. This relationship is demonstrated in the greater use efficiency observed in the high plant density treatment. This result indicates that plant arrangement is an important management practice, considering that the interception of solar radiation is one of the main growth factors for plants. The effect of solar radiation on the growth of seedlings can be observed in several studies, such which the Mazuchowski et al. (2007); Dantas et al. (2009) and Resende et al. (2011).

The high density treatment of seedlings showed a higher percent of intercepted solar radiation (Figure 1F); this response was more pronounced from 150 days after emergence (DAE), where the seedlings intercepted on average $74.72 \%$ of the incident radiation. The medium density treatment intercepted $42.38 \%$ in the same period. This response can be explained by the increase in LAI along the DAE (Fig 1 D). The arrangement of plants is an important management practice; the interaction between the interception of solar radiation and LAI are determinant factors in both the overall growth of seedlings and partitioning of assimilates produced during photosynthesis.

\section{Partitioning of assimilates produced by plants}

Dry matter partition of seedlings showed similar responses between all plant density treatments (Figure 3). Produce dry matter was primarily directed at the shoot apex of seedlings: roots $(50.78 \%)$, leaves $(29.33 \%)$ and stem (19.89\%), percentages represents the mean value over the DAE. This result was also evidenced by Kozlowski et al. (1991), whom reported that the direction of assimilates is of seedlings is geared towards the formation of the plants, which is to say primarily the roots and leaves, and that the proportion between areas of biomass compartmentalization varies according to the age of the plant.

According to Freitas et al. (2005), the seedlings that presented higher radial biomass values saw a better performance after planting; this is likely due to higher area and efficiency for absorbing water and nutrients. Ataíde et al. (2010) reported that the distribution of dry matter produced by plants is fundamental in determining the conversion efficiency and growth potential of seedlings, and that these factors can determine plant capacity and survival in the field. Aside from the physiological advantages displayed by seedlings in the higher density treatments, a higher density of seedlings can result in higher economic returns and efficiency in the use of nursery (Ataíde et al., 2010), as often the empty spaces among seedlings tubes represent a high percentage of areas of the trays.

In the seedlings cultivated in greenhouses, water supply and nutrients are not limiting factors due to the possibility of control for these elements; thus, biomass production is controlled by solar radiation, which was observed and proposed by Caron et al. (2012). So, the growth of Hovenia dulcis seedlings is influenced by the amount of photosynthetically active radiation intercepted, in the utilization efficiency of the energy in the photosynthetic process and the seedling density in the tray. 

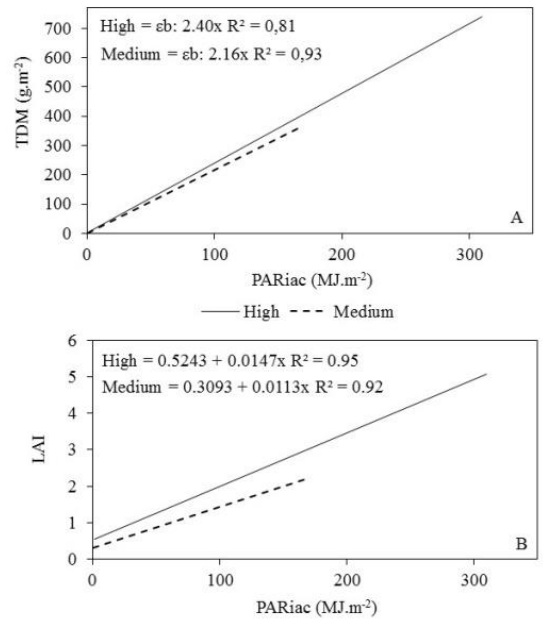

- High - - - Medium

Fig 1. Relation between photosynthetically active radiation intercepted accumulated (PARiac) with the production of dry matter (TDM) (A) and leaf area index (LAI) (B) in two densities of seedlings Hovenia dulcis. Frederico Westphalen - RS, Brasil, 2015.
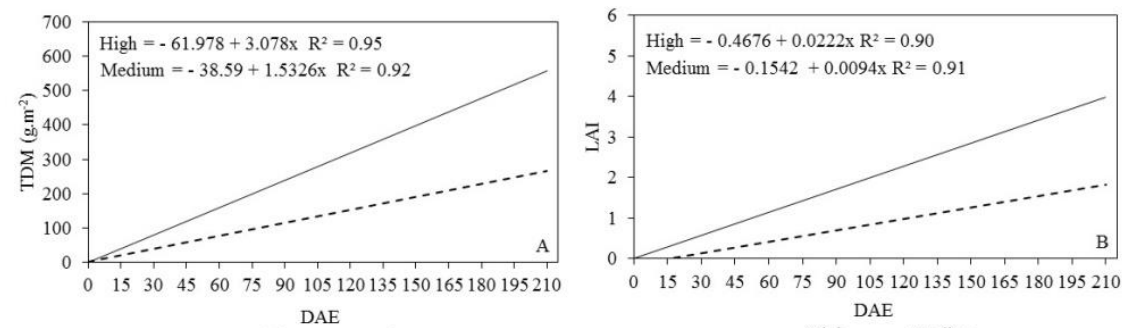

DAE
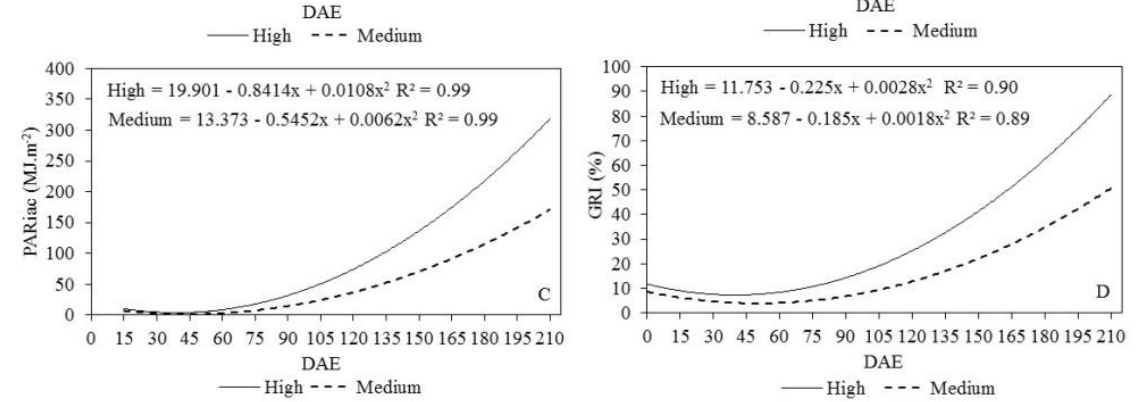

Fig 2. Regression equations for days after emergence (DAE) in relation to the total dry matter (TDM) (A), leaf area index (LAI) (B), photosynthetically active radiation intercepted accumulated (PARiac) (C) and global radiation interception (GRI) (D) in two densities of seedlings Hovenia dulcis. Frederico Westphalen - RS, Brasil, 2015.
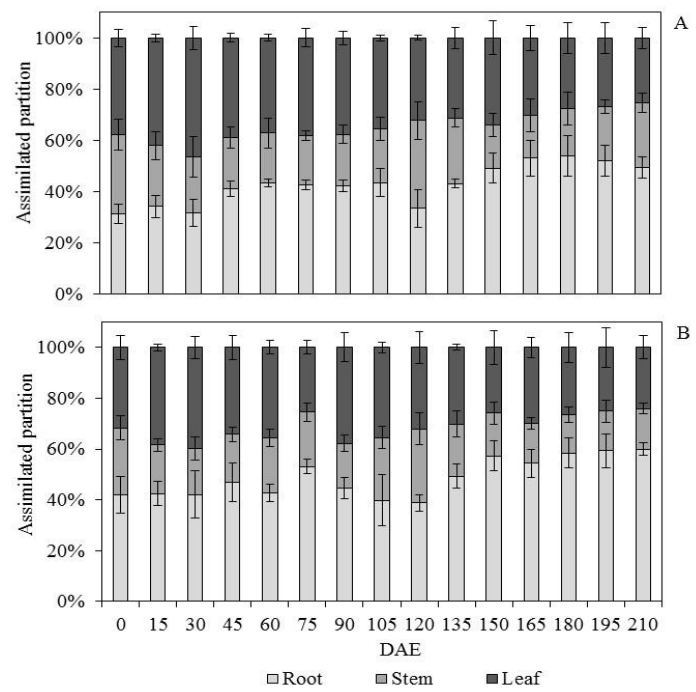

Fig 3. Partition of dry matter of Hovenia dulcis seedlings, in high plant density conditions (A) and medium plant density (B) in the different structural components: root, stem and leaf over the days after emergence, with their respective standard error bars. Frederico Westphalen - RS, Brasil, 2015. 
The results for use efficiency of solar radiation obtained in this study may be applied to various research topics, such as the growth analysis of plants, weather forecast for the cultivar, competition between plants, and estimated production potentials (Manzanares et al., 1993). This study presents a new research field in the area of forestry, and shows that in future studies, the use efficiency of radiation should be prioritized, as it presents a model with good reliability for the estimation of the production potential of Hovenia dulcis seedlings.

\section{Materials and Methods}

\section{Study area and experimental design}

The experiment was conducted in a greenhouse in the tree nursery of the Federal University of Santa Maria, campus Frederico Westphalen - RS, Brazil, with geographic coordinates $27^{\circ} 23^{\prime} 26^{\prime \prime} \mathrm{S} ; 53^{\circ} 25^{\prime} 43^{\prime \prime} \mathrm{W}, 461 \mathrm{~m}$. According to the Köppen climate classification (Alvares et al., 2013), the climate of region is $\mathrm{Cfa}$, ie, humid subtropical with an average annual temperature of $19.1^{\circ} \mathrm{C}$, varying with maximum of $38^{\circ} \mathrm{C}$ and minimum of $0^{\circ} \mathrm{C}$.

In the planning of the treatments, we used a complete randomized block design, where the forest species Hovenia dulcis was evaluated in two levels of plant densities in the tray, $100 \%$ of the usable space in the tray (494 plants $\mathrm{m}^{-2}$ ) and $50 \%$ (247 plants $\mathrm{m}^{-2}$ ), which was denominated high and medium density. In total, fifteen evaluation periods with 6 replicates were carried out, beginning after first emergence. One plant was evaluated in each plot during each evaluation period; in total, six plants were evaluation per period for each individual density. A total of 90 plants were collected in total for all treatments and evaluation periods.

\section{Experimental management}

Sowing was performed directly in conical, open bottom polypropylene seedling tubes, with a volume of $90 \mathrm{~cm}^{3}$. The tubes were placed in plastic trays that held 96 seedlings arranged $1.0 \mathrm{~m}$ above ground level, filled in with a commercial substrate (Tecnomax $\left.{ }^{\circledR}\right)$ which contained slowrelease fertilizer (Basacote $\left.{ }^{\circledR}\right)$ in the quantity of ten grams per liter of substrate.

After 20 days, thinning was performed in order to eliminate excess plants in each seedling tube, leaving only the most central and highest quality seedlings in each tube. During the experiment, the water regime consisted of three daily irrigations with spray nozzles, so that the amount of water on the substrates was maintained at a level near field capacity.

Evaluations were performed every 15 days, the first (considered day zero) occurred $30 \mathrm{DAE}$ and, the last at 210 DAE. The total dry matter (TDM) of the plants was determined from the sum of the compartments: leaf, stem, and roots (Benincasa, 2003). Each component was allocated and identified in individual paper sacks. The sacks were then sent into a forced circulation oven at $60^{\circ} \mathrm{C}$ until a consistent mass was obtained. The samples were later weighed on a precision balance in order to obtain the dry mass of each compartment, which together resulted in the TDM.

\section{Evaluated characteristics}

The extinction coefficient $(\mathrm{K})$ was calculated for each plant density, using the following equation:

$$
\mathrm{K}=-\frac{\ln \left(\frac{\text { Rinf }}{\text { Rsup }}\right)}{\text { LAI }}
$$

Where $\mathrm{k}$ is the extinction coefficient, Rinf is solar radiation measured under the seedling canopy $\left(\mathrm{MJ} \mathrm{m}^{-2}\right)$; Rsup is measured radiation above the plant canopy $\left(\mathrm{MJ} \mathrm{m}^{-2}\right)$; LAI is the leaf area index.

The production of dry matter was based on the model proposed by Monteith (1977), where dry matter production was calculated from intercepted photosynthetically active radiation (PARi) multiplied by the use efficiency. The $\varepsilon b$ can be calculated through the relation between the average production of accumulated TDM and the PARi involved in the production of biomass according to following expression: $\mathrm{TDM}=\varepsilon b^{*}$ PARi, where TDM = total dry matter production $\left(\mathrm{g} \mathrm{m}^{-2}\right)$; PARi $=$ intercepted photosynthetically active solar radiation $\left(\mathrm{MJ}^{-2} \mathrm{~m}^{-2}\right)$ and $\varepsilon b$ is the use efficiency of the radiation in dry matter produced $\left(\mathrm{g}\right.$. $\left.\mathrm{MJ}^{-1}\right)$. The value of for the use efficiency radiation given by the angular coefficient represents the amount of accumulated biomass for each unit of energy intercepted.

Values for intercepted photosynthetically active radiation were determined based on the model proposed by VarletGrancher et al. (1989): PARi $=0.95 *$ (PARinc) $*\left(1-\mathrm{e}^{-\mathrm{K}} *\right.$ LAI), where: PARi $=$ intercepted photosynthetically active radiation $\left(\mathrm{MJ} \cdot \mathrm{m}^{-2}\right)$; PARinc $=$ incident irradiant photosynthetically active radiation $\left(\mathrm{MJ}_{\mathrm{J}} \mathrm{m}^{-2}\right) ; \mathrm{K}=$ extinction coefficient, 0.25 was considered for the two plant densities, a value obtained in the present study; LAI = leaf area index.

The leaf area was obtained by the use of the leaf area integrator, model LI-3000C. The LAI was determined from the total leaf area of each plant $\left(\mathrm{LA}, \mathrm{cm}^{-2}\right)$ and the explored tray area $\left(\mathrm{ETA}, \mathrm{cm}^{-2}\right)$ for each density of seedlings was calculated using the equation: $\mathrm{LAI}=\mathrm{LA} / \mathrm{ETA}$.

The solar radiation in the interior of greenhouse was estimated, from the average transmissivity of the plastic cover of $63 \%$, combined with the incident solar radiation on the exterior of the greenhouse which was measured at each evaluation performed biweekly using a portable pyranometer (LICOR PY32164) coupled to a Datalogger (LICOR 1400). The values of global solar radiation incident were obtained from the Meteorological Station of the Meteorology National Institute, situated about $100 \mathrm{~m}$ from the experiment. The solar radiation inside the greenhouse was calculated based on the following expression: $\mathrm{RGE}=0.63 \times \mathrm{RG}$, where: $\mathrm{RGE}=$ solar radiation in the interior of greenhouse $\left(\mathrm{MJ} \mathrm{m}^{-2}\right)$; $\mathrm{RG}=$ incident solar radiation in the exterior of the greenhouse (MJ $\mathrm{m}^{-2}$ ).

The values of active photosynthetically radiation were estimated as $45 \%$ of global solar radiation. This fraction represents the average values found by Assis and Mendez (1989) and Pandolfo (1995) for the area of Rio Grande Do Sul. The estimate of accumulated photosynthetically active radiation was performed, based on methods by Monteith (1977) and Grancher-Varlet et al. (1989).

Seedlings were collected for analysis every 15 days; the values for GRI was also measured every 15 days, where overall incident radiation for the upper and lower seedling canopy was measured with a portable pyranometer that recorded measurements in the period from 10 to $12 \mathrm{~h}$. The values of intercepted global radiation were obtained according to the following equation: \% Intercepted $=[100-$ $(\mathrm{Rn} \times 100 / \mathrm{Rt})]$ where: $\mathrm{Rn}=$ overall incident radiation on the interior of the canopy; $\mathrm{Rt}=$ overall incident radiation in the upper canopy. 


\section{Statistical analysis}

The data values were analyzed using the software "Statistical Analysis System" (SAS, 2003), which was used in the analysis of variance and regression analysis.

\section{Conclusions}

A high density of seedlings promoted greater efficiency of intercepted photosynthetically active radiation and accumulated dry matter; when compared with the medium density plants for Hovenia dulcis. Seedlings grown under the high density treatment presented a greater leaf area index and percent of intercepted solar radiation, resulting in a greater accumulation of total dry matter. In the literature no reliable information was found regarding the seedlings of Hovenia dulcis. The research presented in this article links the use efficiency of solar radiation with plant growth. In this work, a model is present for analyzing the growth and development of plants and their relation to both photosynthetic rate and radiation use efficiency.

\section{Acknowledgments}

The authors wish to acknowledge the National Council for Scientific and Technological Development (CNPq - Brazil) and the Coordination for the Improvement of Higher Education Personnel (CAPES - Brazil) for their financial support.

\section{References}

Alvares CA, Stape JL, Sentelhas PC, Moraes G, Leonardo J, Sparovek G (2013) Köppen's climate classification map for Brazil. Meteorol Z. 22(6): 711-728.

Assis FN, Mendez MEG (1989) Relação entre radiação fotossinteticamente ativa e radiação global. Pesq Agropec Bras. 24(7): 797-800.

Ataíde G, Castro R, Santana R, Dias B, Correia A, Mendes A (2010) Efeito da densidade na bandeja sobre o crescimento de mudas de eucalipto. R Tróp. 4(2): 21-26.

Benincasa MMP (2003) Análise de crescimento de plantas: noções básicas. Jaboticabal: FUNEP, 41p.

Buriol GA, Streck NA, Petry C, Schneider FM (1995) Transmissividade da radiação solar do polietileno de baixa densidade utilizado em estufa. Ciênc Rural. 25(1): 1-4.

Campoe OC, Stape JL, Nouvellon Y, Laclau JP, Bauerle WL, Binkey D, Le Marie G (2013) Stem production, light absorption and light use efficiency between dominant and non-dominant trees of Eucalyptus grandis across a productivity gradient in Brazil. For Ecol Manage. 288(1): 14-20.

Caron BO, Souza VD, Trevisan R, Schmidt D, Behling A, Bamberg R, Eloy E (2012) Eficiência de conversão da radiação fotossinteticamente ativa interceptada em fitomassa de mudas de eucalipto. Rev Árvore. 36(5): 833842.

Caron BO, Schmidt D, Manfron PA, Behling A, Eloy E, Busanello C (2014) Eficiência do uso da radiação solar por plantas Ilex paraguariensis A. St. Hil. cultivadas sob sombreamento e a pleno sol. Ci Fl. 24(2): 1-9.

Dantas BF, Lopes AP, Silva FFS, Lúcio AA, Batista PF, Pires MMML, Aragao CA (2009) Taxas de crescimento de mudas de catingueira submetidas a diferentes substratos e sombreamentos. Rev Árvore. 33(3): 413-423.
Freitas TA, Barroso DG, José GDA, Penchel RM, Kelly R (2005) Desempenho radicular de mudas de eucalipto produzidas em diferentes recipientes e substratos. Rev Árvore. 29(6): 853-861.

Kozlowski TT, Kramer PJ, Pallardy SG (1991) The physiological ecology of woody plants. New York: Academic Press, 657p.

Manzanares M, Tenorio JL, Manzanares P, Ayerbe L (1993) Yield and development of kenaf (Hibiscus cannabinus L.) crop in relation to water and interception radiation. Biomass Bioenergy. 5(5): 337-345.

Mazuchowski JZ, Silva ET, Maccari JA (2007) Efeito da luminosidade e da adição de nitrogênio no crescimento de plantas de Ilex paraguariensis St. Hil. Rev Árvore. 31(4): 619-627.

Mayers JD, Lawn RJ, Byth DE (1991) Agronomic studies on soybean (Glycine max (L.) Merrill) in the dry seasons of the tropics. II. Interaction of sowing date and sowing density. Aust J Agric Res. 42(7): 1093-1107.

Monteith JL (1977) Climate and the efficiency of crop production en Britain. Proc R Soc B. 281(980): 277-294.

Pandolfo C (1995) Parâmetros básicos para uso na modelagem do rendimento de matéria seca de alfafa (Medicago sativa L.). Dissertação (Mestrado em Agronomia) - Universidade Federal do Rio Grande do Sul, $128 \mathrm{p}$.

Resende SV, Crepaldi IC, Pelacani CR, Brito AL (2011) Influência da luz e substrato na germinação e desenvolvimento inicial de duas espécies de Calliandra Benth: (Mimosoideae-Leguminosae) endêmicas da Chapada Diamantina. Rev Árvore. 35(1): 107-117.

Sanquetta CR, Behling A, Dalla Corte AP, Cadori GC, Junior SC, Macedo JP (2014) Eficiência de conversão da radiação fotossintética interceptada em Fitomassa de mudas de Eucalyptus dunii Maiden em função da densidade de plantas e do ambiente de cultivo. Sci For. 42(104): 573 580.

SAS Statistical Analysis System Learning Edition (2003) Getting started with the SAS Learning Edition. Cary, 200p.

Schumacher MV, Brun EJ, Illana VB, Dissiuta SI, Agne TL (2008) Biomassa e nutrientes em um povoamento de Hovenia dulcis Thun., plantado na Fepagro Florestas, Santa Maria, RS. Ci Fl. 18(1): 27-37.

Stape JL, Binkley D, Ryan MG (2008) Production and carbon allocation in a clonal Eucalyptus plantation with water and nutrient manipulations. For Ecol Manage. 255(3): 920-930.

Taiz L, Zeiger E (2013) Plant Physiology. Porto Alegre: Artmed, 5 ed, 918p.

Varlet-Grancher C, Gosse G, Chartier M, Sinoquet H, Bonhomme R, Allirand JM (1989) Mise au point: rayonnement solaire absorbé ou intercepté par um couvert végétal. Agronomie. 9(5): 419- 439.

Villa Nova NA, Moreira PR, Pereira AB (2003) Eficiência de captura de energia solar por um dossel de Eucalyptus pellita $\mathrm{F}$. Muell sob várias densidades de plantio. RBAgro. 11(2): 63-68 